Original Article

\title{
A NEW ALKALOID FROM DERRIS INDICA (LAM) BENNETT SEED OIL: ISOLATION AND CHARACTERIZATION
}

\author{
NUZHAT TABASSUM, VIDYASAGAR G. M.* \\ Medicinal Plants and Microbiology Research Laboratory, Department of Post-Graduate Studies and Research in Botany, Gulbarga \\ University, Kalaburagi 585106, Karnataka, India \\ Email: gmvidyasagar@gmail.com
}

Received: 16 Sep 2020, Revised and Accepted: 14 Feb 2021

ABSTRACT

Objective: The aim of the study was to isolate alkaloid compound from seed oil of Derris indica (Lam) Bennett where relevant antimicrobial properties in traditional medicines.

Methods: The plant was selected based on their usage in traditional medicines and ethnopharmacological importance. Crude extract from $D$. indica seeds fractioned with different solvents through column chromatography. Isolated pure fraction was identified and characterized using UV, FTIR, ${ }^{1} \mathrm{HNMR}$ and Mass spectroscopy.

Results: $D$. indica seeds hexane extract on fractionation with ethyl acetate and methanol through column chromatography yielded a crystalline fraction. The fraction was identified as alkaloid group and characterized as a 2-(6-methoxyphenanthridin-8-yl) propan-2-ol. The compound is a new report from $D$. indica seed oil.

Conclusion: The usage of $D$. indica plant is much in traditional health care for treatment of diseases. Isolation of alkaloid compound from $D$. indica seeds in traditional herbal medicines may be found a good source of drug discovery.

Keywords: Derris indica, Seed, Phytochemical analysis, Alkaloid

(C) 2021 The Authors. Published by Innovare Academic Sciences Pvt Ltd. This is an open access article under the CC BY license (https://creativecommons.org/licenses/by/4.0/) DOI: https://dx.doi.org/10.22159/ijpps.2021v13i4.39754. Journal homepage: https://innovareacademics.in/journals/index.php/ijpps.

\section{INTRODUCTION}

The medicinal plants always played an important role in the global health and providing a new area of drug research [1]. Since from numerous years, there is increasing a great demand in developing and developed countries for plant-based medicines, food supplement, health products, pharmaceuticals, and cosmetics. Majority of peoples rely on natural products as they are non-toxic, have lesser side effects and easily available [2]. Secondary metabolites have been developed in nature form of different plant species, insects, fungi, algae, and prokaryotes during evolution in enormous diversity. Plant secondary metabolites, such as phenolic compounds, flavonoids, alkaloids, and tannins are reported to exert numerous biological properties $[3,4]$. The alkaloids are among the most important active components in plants and important classes of secondary metabolites which are found to possess important pharmacological properties like analgesic, muscle relaxant, antioxidant, anticancer, antibacterial activities, etc. Hence, responsible for many therapeutic properties in natural medicine and found beneficial for certain life-threatening diseases [3, $5,6]$. Therefore, there is urgent need to discover new therapeutic compounds with diverse chemical structures and with novel mechanism of action is required for new and emerging infectious diseases [7].

Derris indica (Lam) Bennett, a medium-sized evergreen, fast growing, glabrous, deciduous nitrogen fixing, bio-diesel tree belonging to the family Fabaceae, widely distributed in the region of south-east Asia and Pacific Islands [8]. Seeds containing 30-40\% oil, used for treating various diseases such as piles, skin diseases, bronchitis, whooping cough, fever, ulcers etc $[8,9]$. D. indica plant has various types of chemical compounds [10]. There are several reports on presence of wide range of flavonoids in plant with antimicrobial activity [11-23]. Numerous compounds have been isolated and reported, such as karanjin, pongapin, kanjone, pongaglabrone, Pongamosides A, B and C, and a flavonol, glucoside and pongamoside $D$, Pongaglabol and pinnatin $[14,24-26]$. Biologically active compounds obtained from plant sources have always been a great interest for scientists working on infectious and non-infectious diseases [27]. Therefore, the aim of the present investigation is to isolate alkaloid compound from the $D$. indica seeds.

\section{MATERIALS AND METHODS}

\section{Plant material}

Mature seeds of $D$. indica were collected from Gulbarga University campus and local areas of Kalaburagi district, Karnataka. The plant species initially identified by a field guide and later confirmed by herbarium with a voucher specimen (No. HGUG-206) of $D$. indica deposited in the herbarium centre, Department of Botany, Gulbarga University, Kalaburagi, Karnataka, India and also with literatures [28-30].

\section{Extraction and isolation of compound}

Seeds were washed with water, shade dried for 8-10 d at room temperature and pulverized using a grinder. The seed powder was stored in air tight container for further extraction. Dried seed powder was subjected to Soxhlet extractor for extraction with 500 $\mathrm{ml}$ of n-hexane for $48 \mathrm{~h}$ at $40{ }^{\circ} \mathrm{C}$ and filtered. Further, extract was subjected to thin-layer chromatography (TLC) on silica gel-G plates (Hi-media, Mumbai, India) using solvent system ethyl acetate and methanol $(7: 3 \mathrm{v} / \mathrm{v})$ used as mobile phase to separate alkaloid on stationary phase. After development, Dragendroff's reagent test was carried out for detection of alkaloid.

For isolation of compound, obtained extract was dissolved in hexane and consecutively, $10 \mathrm{~g}$ of soluble fractions was subjected to column chromatography (Silica gel-H, 60-120Mesh, Hi-media, Mumbai, India) using solvents, n-hexane, hexane, petroleum ether, chloroform, ethyl acetate, methanol (Sd-fine, Mumbai, India) to afford $200 \mathrm{ml}$ fractions each. Subsequently, elution was carried out by gradual changing the concentration $(90: 10,80: 20,70: 30,60: 40$ $50 ; 50,40: 60,30: 70,20: 80$ and 10:90 v/v) of above mentioned solvents. During elution flow rate was set to $5-10$ drops/min. using vacuum evaporator each fraction was concentrated and subjected to 
TLC. Spots was visualized by spraying with $40 \% \mathrm{H}_{2} \mathrm{SO}_{4}$ (v/v) followed by heating at $80{ }^{\circ} \mathrm{C}$ for $15 \mathrm{~min}$ and TLC plate was detected under visible light. Fraction-2, yielded single spot on TLC was collected. Purity of compound was confirmed by performing TLC studies by using different solvent system as mobile phase. Plates were sprayed with Dragendroff's reagent. Fraction- 2 obtained fine crystals, further purified by recrystallization from methanol to provide pure compound respectively. Obtained compound was further identified by UV, FTIR, LCMS and ${ }^{1}$ HNMR analysis and compared with literature data.

\section{Characterization of isolated compound D2}

Melting point of obtained fraction was determined by Thiele tube melting point apparatus. A UV/VIS spectrum was obtained in the range of 200-800 $\mathrm{nm}$ wavelengths using a 5704SS ELICO spectrophotometer. The Fourier transform infrared (FTIR) spectrum was measured with a $\mathrm{KBr}$ discs in wave numbers $\left(\mathrm{cm}^{-1}\right)$ in the range of $4000-450 \mathrm{~cm}^{-1}$ recorded as inverted peaks using Perkin-Elmer RX1 spectrophotometer. Obtained fraction was subjected to mass spectrometry analysis (MS) to determine molecular ions present in isolated compound. Fraction was analyzed and measured in $\mathrm{CDCl}_{3}$ (denaturated chloroform, DMSO) with a Shimadzu MS 2010 A (temperature of $27^{\circ} \mathrm{C}$ ) using M-nitrobenzyl alcohol (NBA) as matrix. The retention index was determined relative to the retention times in JEOl Model GSx 400 spectrometer. NMR was performed to determine the structure of the compound, ${ }^{1} \mathrm{HNMR}$ was recorded using Bruker AMX $400 \mathrm{NMR}$ spectrometer at $300 \mathrm{~K}$ in $\mathrm{CDCl}_{3}$ and chemical shift was recorded in $\delta(\mathrm{ppm})$ and $\mathrm{J}$ in hertz value relative to Tetramethyl saline (TMS) as internal reference at $400.137 \mathrm{MHz}$.

\section{RESULTS AND DISCUSSION}

\section{Identification and characterization of isolated compound D2}

In the present study compound D2, obtained as a pale yellow colour crystals (hRf: 86.66) in TLC (ethyl acetate: methanol, 7:3) and melting point was recorded as $136-138{ }^{\circ} \mathrm{C}$. UV spectrum showed $\mathrm{UV}^{\lambda_{\max }} \mathrm{nm}$ wavelength at 653.5 and absorbance at 0.262 (fig. 1). The FTIR spectrum shows the presence of broad main absorption band of Hydroxyl group $(-\mathrm{OH})$ at $3358 \mathrm{~cm}^{-1}$ and additional moderate intense bands $1059 \mathrm{~cm}^{-1}, 1275 \mathrm{~cm}^{-1}$ and 1360 $\mathrm{cm}^{-1}$ present between the ranges $\left(600 \mathrm{~cm}^{-1}-1600 \mathrm{~cm}^{-1}\right)$. Band 2930 $\mathrm{cm}^{-1}$ is due to stretching $(\mathrm{C}-\mathrm{H})$ and $1652 \mathrm{~cm}^{-1}$ shows stretching of $\mathrm{C}=\mathrm{N}$ group (fig. 2). The Mass spectrum indicated the molecular ion peak at m/z 267 and base ion peak at m/z 191(fig. 3). Its molecular formula was assumed as $\mathrm{C}_{17} \mathrm{H}_{17} \mathrm{NO}_{2}$ and molecular weight is 267.33 . The ${ }^{1} \mathrm{H}$ NMR spectrum of compound D2 showed signal at $\delta_{\mathrm{H}} 8.20(1 \mathrm{H}, \mathrm{dd}, \mathrm{J}=4 \mathrm{~Hz})$, and multiplet between $\delta 7.77-$ 7.19 characteristic to aromatic protons, one methoxy protons $\left[\delta_{\mathrm{H}}\right.$
$3.95(3 \mathrm{H}, \mathrm{S})]$, two methyl and hydroxyl protons exhibited signals between $\left[\delta_{\mathrm{H}} 2.0(1 \mathrm{H}\right.$, br $\left.\mathrm{S})-1.27(3 \mathrm{H}, \mathrm{S})\right]$. The physico-chemical properties and spectroscopic data indicated that compound D2 as alkaloid and considering the comparative results of spectral studies and structure of D2 was predicted as, 2-(6-methoxyphenanthridin8-yl) propan-2-ol as shown in fig. 4. These spectroscopic data support the proposed structure D2 (fig. 4, table 1). The structure of compound was established on the basis of spectroscopic studies.

Table 1: ${ }^{1} \mathrm{H}$ NMR Data for isolated compound D2 $(400.137 \mathrm{MHz}$, $\delta$ in ppm, $J$ in $\mathrm{Hz}$ )

\begin{tabular}{ll}
\hline Position & $\mathbf{1}^{\mathbf{a}}$ \\
\hline 3 & $8.20(1 \mathrm{H}, \mathrm{dd}, \mathrm{J}=4 \mathrm{~Hz})$ \\
4 & $7.46(1 \mathrm{H}, \mathrm{d}, \mathrm{J}=6.08 \mathrm{~Hz})$ \\
5 & $7.19(1 \mathrm{H}, \mathrm{S})$ \\
6 & $7.46(1 \mathrm{H}, \mathrm{d}, \mathrm{J}=6.08 \mathrm{~Hz})$ \\
9 & $7.46(1 \mathrm{H}, \mathrm{d}, \mathrm{J}=6.08 \mathrm{~Hz})$ \\
10 & $7.28(1 \mathrm{H}, \mathrm{S})$ \\
13 & $1.27(3 \mathrm{H}, \mathrm{S})$ \\
14 & $2.0(1 \mathrm{H}, \mathrm{br} \mathrm{S})$ \\
15 & $1.2(3 \mathrm{H}, \mathrm{S})$ \\
16 & $7.46(1 \mathrm{H}, \mathrm{d}, \mathrm{J}=6.08 \mathrm{~Hz})$ \\
20 & $3.95(3 \mathrm{H}, \mathrm{S})$ \\
\hline
\end{tabular}

aRecorded in $\mathrm{CDCl}_{3}$

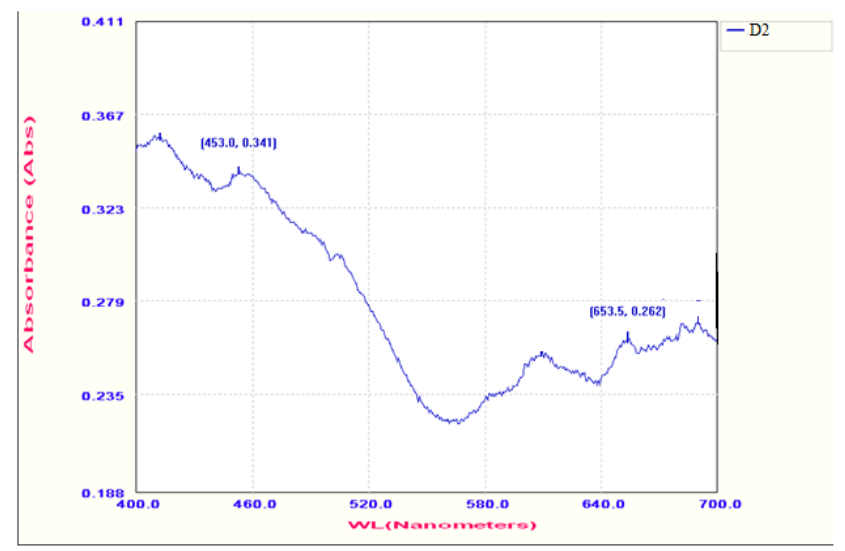

Fig. 1: UV spectrum of isolated compound D2

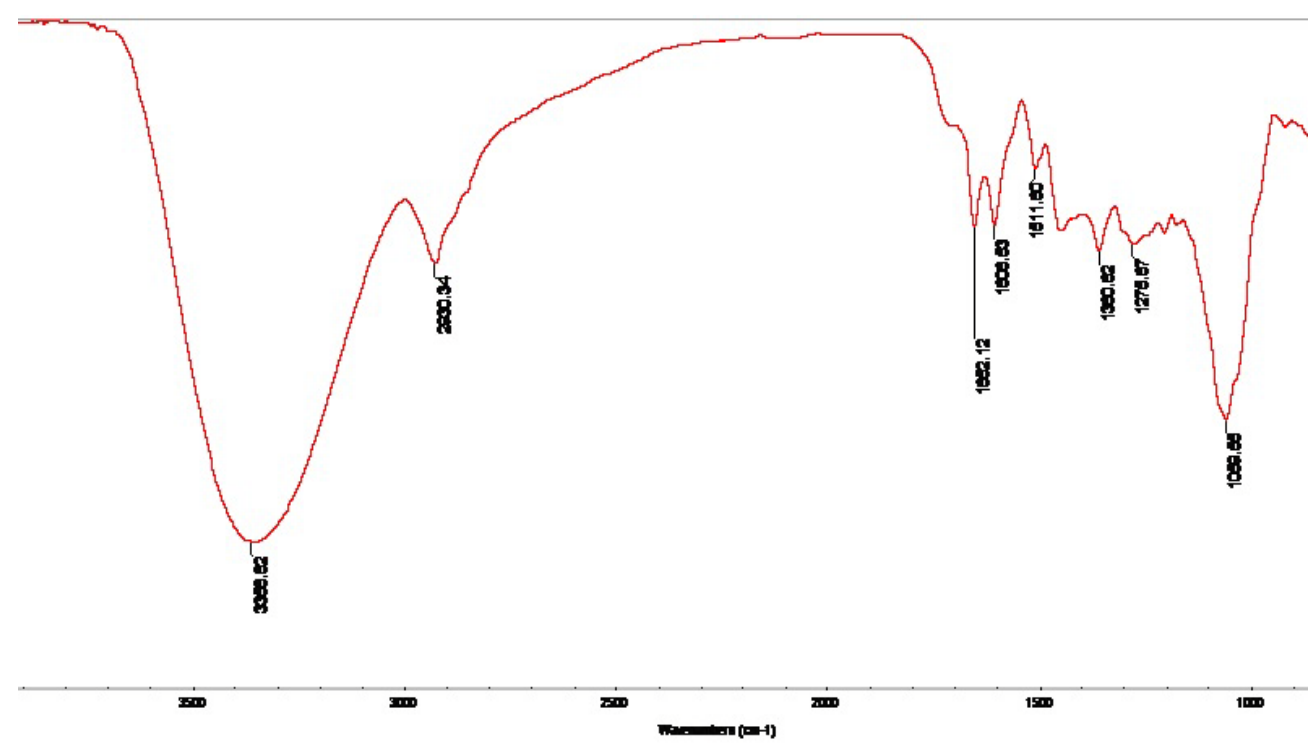

Fig. 2: FTIR spectrum of isolated compound D2 


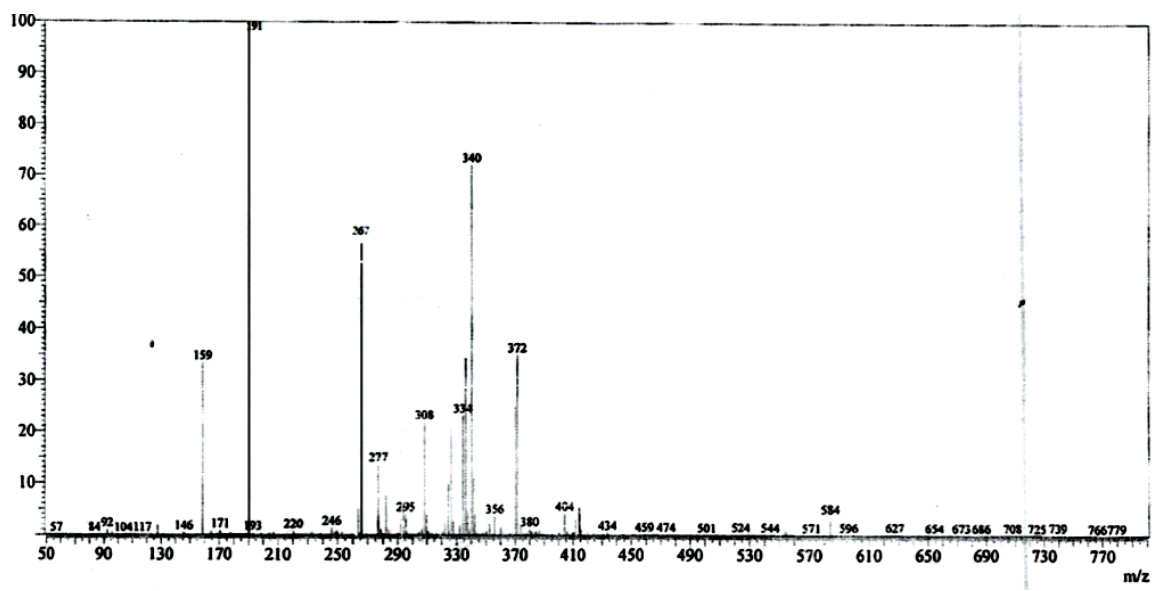

Fig. 3: Mass spectrum of isolated compound D2<smiles>COc1nc2ccccc2c2ccc(C(C)(C)O)cc12</smiles>

Fig. 4: Structure of isolated compound 2-(6methoxyphenanthridin-8-yl) propan-2-ol

According to reports, alkaloids are secondary metabolites originally defined as pharmacologically active compounds, primarily composed of nitrogen [31]. Presence of furanoflavones and isolated numerous phytocompounds from $D$. indica seeds have previously reported by many authors [32-35], Pongamol [36-38] and, Furanodiketon [39], Karanjachromene[40]isopongachromene [39], isoponga flavone [41], 0-methyl pongaglabol [38], 3,3 $3^{1}, 4^{1}, 7-$ tetramethoxyflavone [39], and some fatty acids [42], Pongamoside D [15]. The other flavonoid includes Glabrachalcone, isopongachromene, Karangin, Glabrachalcone, Isopongachromene [43]. A new crystalline compound Pongamol isolated from Pongamia oil which crystallizes from alcohol was reported [44]. Pongapin (II) has been isolated from the ethanolic extract of seed of $P$. pinnata. The residue crystallized from methanol gives a colourless needle [33]. Pongol, a new furanoflavone, obtained as shining yellow needles from ethanol [34].

Several researchers reported that the alkaloids, phenols, triterpenoids, glycosides and tannins, have high potential that can be developed as antimicrobial compounds against pathogenic microorganisms [45, 46]. Natural antimicrobial compounds derived from secondary metabolite play a significant role that provide as resistance mechanisms against many microorganisms [47-50]. After reviewing literatures, this is the first time report of occurrence of alkaloid compound from $D$. indica seed oil and to the best of our knowledge; no other studies have been reported. In these viewpoints, there is an increasing demand for effective antimicrobial agents, justifying in searching new antimicrobial alkaloid drugs.

\section{CONCLUSION}

In traditional systems of medicines, $D$. indica has been widely used for variety of ailments. The literature survey revealed that $D$. indica is an important medicinal plant and shows the presence of many phytoconstituents responsible for varied medicinal properties. Alkaloid compound D2 with desirable phytochemical, certainly encourages future advanced research and provides a significant basis for the development of pharmaceutical drug.

\section{ACKNOWLEDGEMENT}

Authors wish to thanks the University Grants Commission, New Delhi, for providing financial assistance through Maulana Azad National fellowship. Authors are also thankful to Dr. Sheikh Rahber, Department of Chemistry, Gulbarga University, Kalaburagi, Karnataka, India, for characterization.

\section{AUTHORS CONTRIBUTIONS}

Vidyasagar GM designed the experiment and involved in the interpretation of data. Nuzhat Tabassum carried out the experimental work, analysis of data and manuscript preparation. Authors went through the final manuscript.

\section{CONFLICTS OF INTERESTS}

The authors declare that they have no conflicts of interest.

\section{REFERENCES}

1. Desai AG, Qazi GN, Ganju RK, El-Tamer M, Singh J, Saxena AK, et al. Medicinal plants and cancer chemoprevention. Curr Drug Metab 2008;9:581-91.

2. Verma N, Jha K, Chaudhary S, Singh O, Kumar A. Phytochemistry, pharmacology and traditional uses of Leptadenia pyrotechnica-an important medicinal plant. Indian J Pharm Biol Res 2014;2:128-34.

3. Nithya TG, Jayanthi J, Ragunathan MG. Antioxidant activity, total phenol, flavonoid, alkaloid, tannin, and saponin contents of leaf extracts of Salvinia molesta D. S. Mitchell (1972). Asian J Pharm Clin Res 2016;9:200-3.

4. Oksman Caldentey KM, Inze D. Plant cell factories in the postgenomic era: new ways to produce designer secondary metabolites. Trends Plant Sci 2004;9:433-40.

5. Arpita Roy. A review on the alkaloids an important therapeutic compound from plants. Int J Plant Biotechnol 2017;3:1-9.

6. Farah A Al-Marzook, Rabab Omran. Cytotoxic activity of alkaloid extracts of different plants against breast cancer cell line. Asian J Pharm Clin Res 2017;10:168-71.

7. Barbosa LN, Rall VL, Fernandes AA, Ushimaru PI, da Silva Probst I, Fernandes A Jr. Essential oils against foodborne pathogens and spoilage bacteria in minced meat. Foodborne Pathog Dis 2009;6:725-8.

8. Sowjanya P, Srinivasa BP, Neelima LD, Navyasri N, Harshini Y, Vyshnavi J, et al. A phytopharmacological review on a versatile medicinal plant: Pongamia pinnata (L.) pierre. J Pharmacogn Phytochem 2018;7:459-63.

9. Savita S, Rao DV, Sharma RA. A review on Pongamia Pinnata (L.) pierre: a great versatile leguminous plant. Nat Sci 2010;8:130-9.

10. Chopade VV, Tankar AN, Pande VV, Tekade AR, Gowekar NM, Bhandari SR, et al. Pongamia pinnata: phytochemical constituents, traditional uses and pharmacological properties: a review. Int J Green Pharm 2008;2:72-5. 
11. Pankaj K, Rakesh P. An phytochemical overview of various parts of Pongamia pinnata (karanj). World J Pharma Res 2012;2:146-65.

12. Koysomboon S, Altena IV, Kato S, Chantrapromma K. Antimycobacterial flavonoids from Derris indica. Phytochemistry 2006;67:1034-40.

13. Li LY, Li X, Shi C, Deng ZW, Fu HZ, Proksch P, et al. Pongamone A-E, five flavonoids from the stems of a mangrove plant, Pongamia pinnata. Phytochemistry 2006;67:1347-52.

14. Yin $\mathrm{H}, \mathrm{Wu}$ J, Nan $\mathrm{H}$, Zhang $\mathrm{S}$. New prenylated flavones from Pongamia pinnata. Pharmazie 2006;61:76-8.

15. Ahmad G, Yadav PP, Maurya R. Furanoflavonoid glycosides from Pongamia pinnata fruits. Phytochemistry 2004;65:921-4.

16. Yadav PP, Ahmad G, Maurya R. Furanoflavonolds from Pongamia pinnata fruits. Phytochemistry 2004;65:439-43.

17. Carcache Blanco EJ, Kang YH, Park EJ, Su BN, Kardono LBS, Riswan S, et al. Constituents of the stem bark of Pongamia pinnata with the potential to induce quinone reductase. J Nat Prods 2003;66:1197-202.

18. Simin K, Ali Z, Khaliq-Uz-Zaman SM, Ahmad VU. Structure and biological activity of a new rotenoid from Pongamia pinnata. Nat Prod Lett 2002;16:351-7.

19. Chauhan D, Chauhan JS. Flavonoid glycosides from Pongamia pinnata. Pharm Bio 2002;40:171-4.

20. Tanaka T, Iinuma M, Yuki K, Fujii Y, Mizuno M. Flavonoids in root bark of Pongamia pinnata. Phytochemistry 1992;31:993-8.

21. Tanaka T, Iinuma M, Yuki K, Fujii Y, Mizuno M. Two new betahydroxychalcones from the root bark of Pongamia pinnata. Chem Pharm Bull 1991;39:1473-5.

22. Kanungo PD, Ganguly A, Guha A, Bhattacharyya A, Adityachaudhury N. Glabone, a new furanoflavone from Pongamia glabra. Phytochemistry 1987;26:3373-4.

23. Pathak VP, Saini TR, Khanna RN. Isopongachromene, a chromenoflavone from pongamia glabra seeds. Phytochemistry 1983;22:308-9.

24. Talapatra SK, Mallik AK, Talapatra B. Isopongaglabol and 6methoxyisopongaglabol, two new hydroxyfuranoflavones from Pongamia glabra. Phytochemistry 1982;21:761-6.

25. Rastogi RP, Mehrotra BN. Compendium of Indian medicinal plant. Central Drug Research Institute and Publication and information Directorate, New Delhi, India; 1993.

26. Talapatra SK, Mallik AK, Talapatra B. Pongaglabol, a new hydroxyfuranoflavone, and aurantiamide acetate, a dipeptide from the flowers of Pongamia glabra. Phytochemistry 1980;19:1199-202.

27. Heena ARS, Vandana J. A novel, simple, rapid RP-HPLC method for simultaneous estimation of ferulic acid, quercetin, piperine and thymol in Ayurvedic formulation. Int J Appl Pharm 2018;10:303-8.

28. Seetharam YN, Kotresh K, Uplokar SB. Flora of Gulbarga District. Publisher Gulbarga University, Gulbarga; 2000.

29. Saldanha CJ. Flora of Karnataka. Vol. 1-2. Oxford and IBH publishers, New Delhi; 1984a.

30. Gamble JS. Flora of presidency of madras. Adlord and Son Ltd. W. C. London Vol. I. II and III; 1935.
31. Ziegler, Facchini. Alkaloid biosynthesis: metabolism and trafficking. Annual Rev Plant Bio 2008;59:735-69.

32. Soliven FA. The proximate chemical composition of the seed and oil of Philippine oil-bearing seeds: I. Pongamia pinnata merr. Philipp. Agric 1934;23:576-87.

33. Khanna RN, Seshadri TR. Chemical components of Pongammia Pinnata: seeds, flowers and stem bark. Lett Editor. Curr Sci 1964;21:614-45.

34. Roy D, Khanna RN. Structure of synthesis of pongol a new component from the immature seeds of Pongamia glabra. Indian J Chem 1979;18B:525-8.

35. Pathak VP, Saini TR, Khanna RN. Isopongachromene, a chromenoflavone from Pongamia glabra seeds. Phytochemistry 1983;22:308-9.

36. Narayanaswamy S, Rangaswamy S, Seshadri TR, Chemistry of pongamol. Part II. J Chem Soc 1954. p. 1871-3.

37. Khanna RN, Seshadri TR, Pongaglabrone, a new component of the seed of Pongamia glabra its constitution and synthesis. Tetrahedron 1963;19:219-25.

38. Pathak VP, Saini TR, Khanna RN. Glabrachalcone, a chromenochalcone from Pongamia glabra seeds. Phytochemistry 1983a;22:1303-4.

39. Pathak VP, Saini TR, Khanna RN. Chemical constituents of Pongamia pinnata seed. Phytochemistry 1983b;22:308.

40. Naghmana R, Muhammad SAA, Muhammad KT, Nurdiyana MY, Bohari MY. Isolation and crystal structure of Karanjachromene. Anal Sci 2008;24:21-2.

41. Roy D, Sharma NN, Khanna RN. Structure and synthesis of isopongaflavone, a new component of the seeds of Pongamia glabre. Indian J Chem 1977a;15:1138-9.

42. Upadhya GS, Narayanaswami G, Kartha ARS. Note on the comparative development of fatty acids in ripening seeds of 16 dicot species producing C16-C18 acid fats. Indian J Agric Sci 1974;44:620-2.

43. Rahul DY, Jain SK, Shashi A, Prajapati SK, Amita V. Pongamia pinnata an overview. Int J Pharm Sci Res 2011;2:496.

44. Rangaswami S, Seshadri TR. Pongamol, a new crystalline compound from Pongamia oil. Lett Editors Curr Sci 1940;4:179.

45. Hutchings A, Scott AH, Lewis G, Cunningham A. Zulu medicinal plants: an inventory. University of Natal Press, Scottsville, Pietermaritzburg South Africa; 1996. p. 195-6.

46. Karamanoli K. Secondary metabolites as allelochemicals in plant defence against microorganisms of the phyllosphere. In: Reigosa M, Pedrol N. Eds. Allelopathy from molecules to ecosystems. Science Publishers Inc, NH USA; 2002. p. 277-88.

47. Hanson JR. Natural products the secondary metabolites. The royal society of chemistry, Cambridge, UK; 2003. p. 1-27.

48. Sarker SD, Latif Z, Gray AI. Natural products isolation. 2nd Edition. Humana Press: New Jersey, United States of America; 2006.

49. Sasmita P, Sujata M. Evaluation of antibacterial activity of Pongamia pinnata L., Curcuma longa L. and Mentha arvenis L. against Staphylococcus aureus. Int J Chem Tech Res 2016;9:205-12.

50. Cowan MM. Plant products as antimicrobial agents. Clin Microbiol Rev 1999;12:564-82. 